\title{
Does Foliar Application of Macro and Micronutrients Have Any Impact on Roses Production? A Review
}

\author{
Hafiz Muhammad Bilal $^{1 *}$, Rohoma Tahir ${ }^{1}$, Muhammad Adnan $^{2 *}$, Syed Mukarram Ali ${ }^{3}$, Haseeb Islam ${ }^{1}$, Muhammad \\ Shakeeb Umer ${ }^{1}$, Farman Ali Mir ${ }^{4}$, Rai Iklaq Ahmed ${ }^{1}$ and Muhammad Iftikhar ${ }^{1}$
}

${ }^{1}$ Department of Horticulture, College of Agriculture, University of Sargodha, Pakistan

${ }^{2}$ Department of Agronomy, College of Agriculture, University of Sargodha, Pakistan

${ }^{3}$ Department of Mathematics, University of Sargodha, Pakistan

${ }^{4}$ Department of Horticulture, Crop and Food Sciences Pir Mehr Ali Shah Arid Agriculture University, Rawalpindi, Pakistan

Submission: August 17, 2020; Published: September 09, 2020

"Corresponding author: Muhammad Adnan, Department of Agronomy, College of Agriculture, University of Sargodha, Pakistan and Hafiz Muhammad Bilal, Department of Horticulture, College of Agriculture, University of Sargodha, Pakistan

\begin{abstract}
In all over the world rose plants are most widely cultivated and supreme plants among all ornamental plants. However, production and quality are poor due to insufficient knowledge, non-technical skills and the most important inadequate dose and application of method of fertilizers application. The quality and yield of roses directly depends on the balanced and proper application of macro and micronutrients. Most of the traditional framers prefers to apply nutrients in soil but it causes many losses. Therefore, application of fertilizer through an efficient method allows the plant to absorb the nutrients in shorter time. Foliar fertilization is the most appropriate method of providing balanced plant nutrition in horticulture. It provides the immediate translocation of nutrients to various plant organs via leaf tissues under various nutrient deficiencies. The present review focuses on the role of foliar application of macro and micronutrients on yield and quality of roses and demonstrates that foliar application of macro and micronutrients have great impact on roses growth, yield and quality.
\end{abstract}

Keyword: Roses; Poor Production; Foliar Application; Macro and Micronutrients

\section{Introduction}

Rose plants are the most imperative attractive plants in all our world [1]. Rose (Rosa spp.) belongs to the Rosaceae family. It is native to the northern hemisphere and is mainlygrown in temperate zones. Rose is one of the most important cut flowers [2]. They are cultivated for aesthetics purpose, but numerous species of roses have correspondingly important pharmaceutical appositeness. There are many cultivars and species available that are cultivated in various environment across the world [3]. However, production and quality are poor due to insufficient knowledge, non-technical skills and the most important inadequate dose and application of method of fertilizers application. Most of the soils have high $\mathrm{pH}$ value (alkaline), which hinders the absorption of micronutrients [4]. When nutrient shortage cannot be corrected through soil application then foliar nutrition is an alternate method to correct those problems [5-7]. Due to high pH value of sandy desert soil, application of fertilizers through foliar spray may be helpful in these conditions to keep away from the soil fixation of some micronutrients [8]. Foliar application is very important strategy for plant nutrient management [9]. Foliar fertilization of nutrients can be a useful method of providing balanced plant nutrition in horticulture [10]. Many studies have highlighted the benefits of foliar fertilization in improving plant growth, crop yield, nutrient uptake and product quality. This technique can ensure immediate translocation of nutrients to various plant organs via leaf tissues under various nutrient deficiencies [11,12]. According to literature survey, many reports are available about foliar fertilizers on many plants as chrysanthemum, rose, tuberose and iris plants [13,14]. Micronutrients such as Fe, Mn, B, Cu, Zn, Mo, $\mathrm{Ni}$ and Co are necessary in much lesser amount and essential for plant intensification than those of the primary nutrients [15]. These are essential because of their immense connotation and involvement to enzyme system in metabolism. Foliar application of micronutrients may be six to 20 times more efficient than soil application in increasing crop production and other growth 
parameters [16]. The present review focuses on the role of foliar application of macro and micronutrients on yield and quality of roses and demonstrates that foliar application of macro and micronutrients have great impact on roses growth, yield and quality.

\section{Effect of Foliar Application of Macro Nutrients on Roses}

Macronutrients plays a very important role in plant growth and development. Their function ranges from being structural units to redox-sensitive agents. Generally, application of macronutrients increases yield, growth, and quality of crops. In the recent years, plant physiologists, biotechnologists and eco-physiologists have been working to investigate various other blind features of these minerals and their future prospective because nutrients are involved in every step of plant life. Every macronutrient has its own character and is therefore involved in different metabolic processes of plant life [17] performed a trial to check the effect of foliar application of macronutrients on rose plants. They reported that combined application of macronutrients significantly affected the rose production [18] conducted the trial to check the response of growth, yield and flowering of rose cultivar "Gruss-an-taplitz" against the sole and combined application of NPK. They studied plant height, flower diameters, number of branches, number of flower plants-1, flower diameters and flower weight. This research concluded that sole application of $\mathrm{N}$ and $\mathrm{P}$ significantly affected both vegetative and reproductive parameters. Moreover, flower weight, diameters and yield were also affected by K. However, combined application of all NPK was more effective for flower weight and diameters [19] conducted the experiment to check the effect of soil and foliar application of NPK and $\left(\mathrm{NH}_{4}\right)^{2} \mathrm{SO}_{4}$ on several growth parameters of roses. Different concentration was prepared for foliar and soil application. Application of fertilizers were applied at three different stages, namely: 1st at seedling stage, $2^{\text {nd }}$ at juvenile stage and 3 rd at pre-flowering stage. However, sole foliar application was not satisfactory [20] conducted the research to check the response of rose plant on different doses of NPK. They reported that the fertilizer level NK (20:12) was best to achieve maximum production.

\section{Effect of Foliar Application of Micronutrients on Roses}

In plant sciences, the prodigious significance of micronutrient is unavoidable since plant relies primarily on micronutrient as it has profound influence on array of plant activities. Although micronutrients are abundantly present in the soil, but plants usually acquire them in relatively trace amounts hence, regarded as trace elements. $\mathrm{B}, \mathrm{Cu}, \mathrm{Fe}, \mathrm{Mn}, \mathrm{Zn}$ are such micronutrients required in minute amounts by plants but inexorably play an eminent role in plant growth and development [21] conducted the research to test the result of foliar spray of micronutrients on quality and quantity of roses (Floribunda). They observed that combination of micronutrients showed significant result in yield and quality of floribunda roses but among all of these treatment
Boric acid (0.5\%)+ $\mathrm{ZnSO}_{4}(0.75 \%)+\mathrm{FeSO}_{4}(1.5 \%)+\mathrm{MgSO}_{4}$ $(0.5 \%)+\mathrm{MnSO}_{4}(1 \%)+\mathrm{CuSO}_{4}(0.3 \%)$ showed superior results as compared to other [22] performed the research to check the effect of foliar application of iron and zinc for the quantity and quality of flowers of tube roses and reported that the among all $\mathrm{ZnSO}_{4}$ doses, $0.4 \%$ enhance the flowering parameters such as stalk length, minimum days to initiation and flower quality etc. They reported that $0.4 \% \mathrm{FeSO}_{4}$ also proved best dose among all the other doses of iron. The contrast doses of Fe and $\mathrm{Zn}$ were non-significant so finally concluded that the $0.4 \%$ of Fe and $\mathrm{Zn}$ is the best level for enhancing the quality and yield [23] conducted the experiment to check the response of foliar application of micronutrients and reported that micronutrient level $0.5 \% \mathrm{ZnSO}_{4}+1.0 \% \mathrm{FeSO}_{4}+0.5 \%$ $\mathrm{MnSO}_{4}+0.2 \%$ Boric acid $0.1 \%$ Citric acid showed significant result for silkworm by increasing weight of larvae, efficient rearing rate, weight of cocoon, weight of shell and cocoon yield, as compared to others treatments [24] conducted the research to check the effect of foliar spray of N, B, Mn and Zn on physiological characteristics of plant. They observed the several parameters like spreading of plant, number of leaves, leaf length, leaf width, total number of suckers' plant 1 . Result indicated that $\mathrm{ZnSO}_{4}+\mathrm{MnSO}_{4}+\mathrm{FeSO}_{4}$ $(0.2 \%+0.2 \%+0.1 \%)$ showed more significant results for total number of leaves, plant spread, leaf length, as compared to other treatments while $\mathrm{ZnSO}_{4}+\mathrm{MnSO}_{4}+\mathrm{FeSO}_{4}(0.4 \%+0.4 \%+0.3 \%)$ produced maximum leaf width.

Conducted the trial to check the response of damask rose against the foliar application of Copper, Magnesium and Zinc sulphate under Western Himalayas [25]. They reported that $\mathrm{ZnSO}_{4}$ and $\mathrm{MgSO}_{4}$ showed the better result in composition of oil and flowering of damask rose [26] performed the research work to check the response of rose bushes in term of growth, flowers and yield against the application of iron doses. Finally, the result of this study was that the doses of Fe effect positively, but the recommended dose of Fe was $3.6 \mathrm{mg} \mathrm{kg}-1$ that enhance the growth and yield of rose bushes cultivar "Shiny Terrazza" [27] Carried the research to check the response of roses against the foliar application of two level of micronutrients $\mathrm{ZnSO}_{4}$ and $\mathrm{FeSO}_{4}$ ). They reported that among all of the treatments $\mathrm{ZnSO}_{4}$ level $0.4 \%$ enhance the flowering parameters such as stalk length, minimum days to initiation, flower quality etc. Also, $\mathrm{FeSO}_{4}$ level $0.4 \%$ also proven best dose among all the other doses of Fe. So, this research recommended the dose of $\mathrm{Fe}$ and $\mathrm{Zn}$ is $0.4 \%$ for the better production [28] conducted the research to check the growth, stalk length, flower diameter, days to flower initiation and length of plant against the application of salicylic acid and Boron. They reported the dose of SA at the rate of $3 \mathrm{mM}$ showered the best result and the dose of B 15 ppm showed the better result among all of the other [29] conducted the research to study the effect of foliar application of Zinc and copper on growth parameters and also the shelf life of Lilium. Positive response was showed by application of micronutrients in this experiment. Almost all doses showed significant result in specific parameters, such as the $\mathrm{Zn}$ 
$0.4 \%+\mathrm{Cu} 0.4 \%$ exhibited the enhancing of leaf area, $\mathrm{Zn} 0.2 \%+\mathrm{Cu}$ $0.2 \%$ showed maximum chlorophyll content and also maximum fresh and dry weight. $\mathrm{Zn} 0.4 \%+\mathrm{Cu} 0.2 \%$ showed the increasing of shelf life of lilium and maximum solution up taking.

Conducted the research to check the results of foliar spray of micronutrients on medicinal plants growth, yield and also fresh and dry weight of roots and shoots [30]. After the application of these fertilizer the result showed that application of nutrients 400 ppm proved the best among all of the others at this concentration oil formation, growth, yield, fresh and dry weight almost all were showed the positive effect. Therefore, this dose was recommended after this research. [31] Performed the experiment to check the outcome of foliar spray of micronutrients on flowering and growth of Gerbera Jamesonii. They reported almost all the levels of nutrients were showed the positive effect on plants as compared to control. So, concluded that the nutrients improved the flowering and growth of Gerbera Jamesonii as compared to the control [32] conducted the experiment to check the response of foliar application of some macronutrients against yield, growth and nutrient concentration in grains of two registered varieties. They observed result showed that both varieties of plant showed significant response against macronutrients. Nutrient contents in grains was significantly affected by $\mathrm{Ca}, \mathrm{Fe}, \mathrm{Zn}, \mathrm{Mn}$ and $\mathrm{K}$ [33]. Conducted the research to investigate the result of foliar application of zinc and manganese sulphate on, yield, fruit quality and leaf nutrition status of pomegranate. Experiment showed that the application of $\mathrm{Zn}$ and $\mathrm{Mn}$ were positive result for most of the character, but their interaction was non-significant. Mn at the rate of 0.3 and $0.6 \%$ showed the better result in some character such as growth, fruit size and quality similar Zn also play significant role for some character like TSS, TSS/TA ratio and juice content. The combination of these two nutrients at the rate of $0.3 \% \mathrm{ZnSO}_{4}$ and $0.6 \% \mathrm{MnSO}_{4}$ is suitable dose for the better growth and yield of pomegranate.

Conducted the research to investigate the response of growth and flowering of roses against the foliar application of micronutrients [34]. They reported the result showed that the combination of nutrients at the rate of $0.3 \%$ showed significant result for vegetative growth including number of branches (primary and secondary), number of leaver shoot-1 and number of leaves plant-1, also this level increase the flower yield and quality but showed minimum result for the initiation of $1^{\text {st }}$ flower bud. [35] conducted this research to check the effect of micronutrients on growth, yield and quality of rose under control condition. They observed result was concluded that the variety Grand Gala showed the best result as compared to Corvette in parameters such as flower yield, stalk length, chlorophyll content, leaf area etc. [36]. Conducted the experiment to check the effect of foliar application of different combination of micronutrient on resistant of plant against salinity. They reported result showed that foliar application of nutrients showed significant result in root features, nutrients reserves and growth of plant [37] carried out the experiment to check the effect of foliar application of micronutrients on plant growth and flowering of three rose cultivars Kardinal, Amalia and Rosy cheeks. They reported this experiment showed that the foliar application of micronutrients improved the plant growth, quality and flower yield. $\mathrm{B}+\mathrm{Zn}$ and all three nutrients combination $(\mathrm{B}+\mathrm{Zn}+\mathrm{Fe})$ was more effective. It is concluded that the combination of these nutrients showed better result instead of their individual application [38]. Carried the experiment to check the effect of foliar application of manganese and iron with uniconazole on yield, chemical content of plant and photosynthetic pigments under salinity. This experiment showed that the salinity affects mostly parameters such as height of plants, no of tillers, weight of spike, grain weight, and also biological yield. It also enhances the photosynthetic pigments and concentration of $\mathrm{K}$ in grains. By this experiment observed that by application of $\mathrm{Mn}$ and Fe photosynthetic pigment in leaves and yield parameters were increased [39] conducted the experiment to observe the effect of application of zinc and boron on sunflower and check the difference of physiological parameters, yield and nutrition absorption of flower. This experiment revealed that application of these nutrients were showed positive affect on mostly parameters and among the dose ( $\mathrm{Zn} 15$ and B 1.5 along with NPK) prove the best for sun flower because at this level of nutrients plant increase their dry matter, leaf area, flower size, seed rate etc. So, they reported concluded that application of $\mathrm{Zn}$ and $\mathrm{B}$ at the rate of $15 \mathrm{Kg} \mathrm{ha}^{-1}$ and $1.5 \mathrm{Kg} \mathrm{ha}^{-1}$ respectively were recommended for the production [40]. Conducted the experiment to observe the response of shelf life of two cultivars of rose Trika and whisky mac against the different concentration of sucrose and silver nitrate. They observed the result of this treatment was positive that the cultivar that were treated with different doses of sucrose and silver nitrate was increase the vase life of flower 3 to 4 days as compared to control.

\section{Effect of Foliar Application of combined Macro- Micronutrients}

Conducted the experiment to check the response of Lilum hybrid cultivar against the foliar application of micro and macronutrients and vitamins solution. Murashige and skoog media was used [41]. They reported the result showed that the application of MS-macro, MS-micro and MS-vitamins showed significant result in qualitative and quantitative parameters like length of flower, length of flower bud, width of flower bud and weight of bulb. Shelf life of flower improved by the application of MS-macro solution alone [42] performed the trial to check the effect of foliar application of nitrogen, boron, manganese and zinc on maize and check the response of physiological characteristics. They observed result of the research showed that foliar application showed the positive effect on all three stages. Zn application on tasseling stage showed highest weight of grain and at seed forming stage foliar application of B showed significant result, $\mathrm{N}$ foliar spray also showed the best result as compared to control that only spray with water [43] conducted the research to check the effect of nitrogen and potassium and some micronutrients on yield and chemical composition of plant. They reported the 
result showed the positively effect on yield, number of tillers, length of plant, weight of spike, number of grains spike 1 . They also observed result revealed that the soil application of $\mathrm{N}$ and $\mathrm{K}$ and foliar application of micronutrients were suitable for growth and yield of plant. [44]. Executed the research work to study the result of foliar spray of micronutrients on photosynthetic rate and yield of citrus fruit. They reported result of foliar application of $\mathrm{Zn}, \mathrm{Cu}$ and $\mathrm{B}$ at the rate of $(0.1 \%, 0.2 \%$, and $0.3 \%)$ respectively showered the improvement in photosynthetic rate, chlorophyll content, transpiration rate, stomatal conductance. $\mathrm{Zn}, \mathrm{Cu}$ and $\mathrm{B}$ $(0.3 \%, 0.1 \%$ and $0.2 \%)$ respectively was proved best for better fruit quality and yield.

Carried out the research to investigate the result of foliar application of macro and micronutrients on growth and yield [45]. They observed result revealed that foliar application of micro and macronutrients showed significant result in growth and yield. Treatment improved the number of flower, flower weight, leaf area, diameter of flower and NPK (15:32:7) + micro power improved the growth and NPK (15:32:7) + Chelated mix micronutrients improved the length of branches, height of plant. So, by this experiment micro and macronutrients foliar spray proved best for yield and growth [46] performed the research to check the response of rose cultivars "Cardinal mac" and "Whisky mac" to different doses of macro and micronutrients. They observed that NPK (15:32:7) and (NPK + micro power) proved the best combination of macro and micronutrients. They also reported that the NPK $(15: 20: 15)+$ Chelated mix micro + VC- 10 (vermi compost) showed less effective result due to the addition of VC- 10 because VC-10 increase the acidity of soil which give low growth and also low quality. The comparison between two cultivars "Cardinal mac" response well as compared with "Whisky mac".

\section{Conclusion}

In all over the world rose plants are most widely cultivated and supreme plants among all ornamental plants. However, production is poor due to inadequate application method of fertilizers. The presents review concluded that foliar application has a great impact on roses production, and it is the easiest and most economical way to improve quality production of rose flowers.

\section{References}

1. Bilal HM, Islam H, Adnan M, Tahir R, Zulfiqar R, et al. (2020) Effect of Salinity Stress on Growth, Yield and Quality of Roses: A Review. Int J Environ Sci Nat Res 25(1): 37-41.

2. Babasheikhali M, Jabbarzadeh Z, Amiri J, Barin M (2020) Impact of salicylic acid and nitric oxide on improving growth and nutrients uptake of rose in alkaline soil conditions. J Plant Nutr 43(5): 667-681.

3. Reis M, Figueiredo JRM, Paiva R, da Silva DP, De Faria CVN, et al. (2016) Salinity in rose production. J Ornam Hortic 22(2): 228-234.
4. Ahsan M, Rehman S, Younis A, Riaz A, Tariq U, et al. (2012) Different strategies to create earliness and enhance quality of tuberose (Polianthes tuberosa L.) CV. Single Asian J Pharm Biol Res 1: 84-88.

5. Halder NK, Ahmad R, Bagam KA, Siddiky MA (2007) Effect of boron and zinc fertilization on corm and cormel production of gladiolus in gray terrace soils of Bangladesh Int J Sustain Crop Prod 2(5): 85-89.

6. Sarkar D, Mandal B, Kundu MC (2007) Increasing use efficiency of boron fertilizers by rescheduling the time and methods of application for crops in India. Plant Soil 301: 77-85

7. Cakmak I (2008) Enrichment of cereal grains with zinc: agronomic or genetic bio fortification. Plant Soil 302: 1-17.

8. El-Naggar AH (2009) Response of Dianthus caryophyllus L. plants to foliar nutrition. World J Agri Sci 5: 622-630.

9. Adnan M, Abbas B, Asif M, Hayyat MS, Raza A, et al. (2020) Role of Micronutrients Bio-Fortification in Agriculture: A Review. Int J Environ Sci Nat Resour 24(4): 209-213.

10. Fageria N, Filho MB, Moreira A, Guimaraes C (2009) Foliar fertilization of crop plants. J plant Nut 32(6): 1044-1064.

11. Singh B, Naruka I, Singh L (1998) Effect of foliar application of nitrogen (Urea) and Gibberellic Acid (GA 3) on growth and yield of Okra (Abelmoschus esculentus L.). Progressive Horticulture 30(3): 175-180.

12. Chattopadhyay S (2003) Response of foliar feeding of boron and molybdenum on growth and yield of okra in Terai Zone of West Bengal. Env Ecol 21(3): 702-705.

13. Al-Humaid A (2002) The influence of foliar nutrition and gibberellic acid application on the growth and flowering of Sntrix rose plants. Alex J Agri Res 46(2): 83-88.

14. Kashif M, Rizwan K, Khan MA, Younis A (2014) Efficacy of macro and micro-nutrients as foliar application on growth and yield of Dahlia hybrida L. (Fresco). Int J Chem 5: 6-10.

15. Brady NC, Ray RW (2000) Elements of the Nature and Properties of Soil. Upper saddle Rover, New Jersy: Prentice-Hill Inc 126-132.

16. Younis A, Riaz A, Sajid M, Mushtaq N, Ahsan M, Hameed M, Tariq U, Nadeem M (2013) Foliar application of macro-and micronutrients on the yield and quality of Rosa hybrida cvs. Cardinal and Whisky Mac. Afr J Biotechnol 12(7): 702-708.

17. Abd-Elall EH, Hussein MA (2018) Foliar application of micro silica, potassium chloride and calcium chloride enhances yield and fruit quality of balady orange tree. Alex Sci Exch J 39: 387-393.

18. Ahmad SF, Ansari MA, Nadeem A, Bakheet SA, AL-Ayadhi LY, Attia SM (2017) Toll-like receptors, NF- $\kappa B$, and IL-27 mediate adenosine A2A receptor signaling in BTBR $\mathrm{T}+\mathrm{Itpr} 3 \mathrm{tf} / \mathrm{J}$ mice. Progress in NeuroPsychopharmacology and Biological Psychiatry 79: 184-191.

19. Iqbal M, Khera RA (2015) Adsorption of copper and lead in single and binary metal system onto Fumaria indica biomass. Chem Int 1(3): 157163.

20. Qadir M, Ghafoor A, Murtaza G, Mahmood T (1997) Metal ion contamination in vegetables and soils irrigated with city effluents Environmental pollution p. 17-21.

21. Ganeshkumar P, Murhekar MV, Poornima V, Saravanakumar V, Sukumaran K, et al. (2018) Dengue infection in India: A systematic review and meta-analysis. Plos Neglect Trop D 12(7): 86-98.

22. Natarajan S, Bajaj HC, Tayade RJ (2018) Recent advances based on the synergetic effect of adsorption for removal of dyes from wastewater using photocatalytic process. J Environ Sci 6(5): 201-222. 
23. Geetha T, Ramamoorthy R, Murugan N (2017) Effect of foliar spray of micronutrients applied individually and in combination on mulberry leaf production, cocoon productivity and profitability. Statistical approaches on multidisciplinary research. Edited by S. Vignesh and A. Philip Arokiadoss. Surragh Publishers India 64-70.

24. Raj D, Sahu S, Anand A (2017) Learning local and global contexts using a convolutional recurrent network model for relation classification in biomedical text. Paper presented at the Proceedings of the $21^{\text {st }}$ conference on computational natural language learning pp. 311-321.

25. Kumar VA, Uchida T, Mizuki T, Nakajima Y, Katsube Y, et al. (2016) Synthesis of nanoparticles composed of silver and silver chloride for a plasmonic photocatalyst using an extract from a weed Solidago altissima (goldenrod). J Nanosci Nanotechno 7(1): 15002-15009.

26. Xavier GC, Soares PC, da Silva Junior VA, de Torres SM, Maymone ACM, et al. (2016) Effect of dietary selenium and vitamin e supplementation on testicular morphology and serum testosterone concentration in goats following scrotal insulation. Acta Sci Vet 44: 1-8.

27. Sharma M, Patel SN, Lata K, Singh U, Krishania M, et al. (2016) A novel approach of integrated bioprocessing of cane molasses for production of prebiotic and functional bioproducts. Bioresour Technol 219: 311318.

28. Massoud AM, Abou-Zaid MY, Bakry MA (2005) Response of pea plants grown in silty clay soil to micronutrients and Rhizobium incubation. Egypt J Appl Sci 20: 329-346.

29. Sampson VB, Yoo S, Kumar A, Vetter NS, Kolb EA (2015) Micro RNAs and potential targets in osteosarcoma. Frontiers in pediatrics 3: 6-9.

30. Chen S, Liu G, Yadegari H, Wang H, Qiao SZ (2015) Three-dimensional $\mathrm{MnO}_{2}$ ultrathin nanosheet aerogels for high-performance $\mathrm{Li}-\mathrm{O}_{2}$ batteries. Journal of Materials Chemistry A 3(6): 2559-2563.

31. Ahmad F, Bashir T (2013) Explanatory of Macroeconomics Variables as Determinant of Non-Performing Loans: Evidence from Pakistan. World Appl Sci J 22(2): 243-255.

32. Ghani A, Hussain S, Zubair M (2013) Assessment of nutritional status of geriatric population in Sargodha city. Int J med Appl health 1(1): 22-38

33. Hasani M, Zamani Z, Savaghebi G, Fatahi R (2012) Effects of zinc and manganese as foliar spray on pomegranate yield, fruit quality and leaf minerals. J Soil Sci Plant Nutr 12(3): 471-480.

34. Pawar S, Mahadkar U, Jagtap D, Jadhav M (2017) Effect of different planting techniques and inputs on yield attributes and yield of rice (Oryza sativa L.) during kharif season. Farm Mana 2(1): 16-21.

35. Dutta P, Mitra U, Dutta S, Naik TN, Rajendran K, et al. (2011) Zinc, vitamin $\mathrm{A}$, and micronutrient supplementation in children with diarrhea: a randomized controlled clinical trial of combination therapy versus monotherapy. J Pediatr 159(4): 633-637.

36. El-Fouly MM, Mobarak ZM, Salama ZA (2011) Micronutrients (Fe, Mn, Zn) foliar spray for increasing salinity tolerance in wheat Triticum aestivum L. Afr J Plant Sci 5(5): 314-322.

37. Ahmad M, Anjum A, Hussain S (2018) The Effect of Micronutrients (B, Zn and Fe) Foliar Application on the Growth, Flowering and Corm Production of Gla diolus (Gladiolus grandiflorus L.) in Calcareous Soils. J Agr Sci Tech 16: 1671-1682.

38. Zeidan M, Mohamed MF, Hamouda H (2010) Effect of foliar fertilization of $\mathrm{Fe}, \mathrm{Mn}$ and $\mathrm{Zn}$ on wheat yield and quality in low sandy soils fertility. World J Agric Sci 6(6): 696-699.

39. Shukla AK, Sinha NK, Tiwari PK, Prakash C, Behera SK, et al. (2017) Spatial distribution and management zones for sulphur and micronutrients in Shiwalik Himalayan Region of India. Land Degra Dev 28(3): 959-969.

40. Butt S, Leon JB, David C L, Chang H, Sidhu S, et al. (2007) The prevalence and nutritional implications of fast food consumption among patients receiving hemodialysis. J Ren Nutr 17(4): 264-268.

41. Giri TK, Beura S, Acharjee S, Palai S (2018) Impact of various nutrients on flowering and bulb production of oriental Lilium hybrid cv. Sorbonne. J Pharm Innov 7(4): 103-106.

42. Haghi AO, Behrouzyar EK, Eivazi A (2016) Morpho-physiological response of maize (Zea mays $L$ ) to $\mathrm{N}, \mathrm{Mg}, \mathrm{S}$ and Fe nutrients foliar application in different growth stages. Int j adv res biol sci 9(3): 338343.

43. Mohamed SG, Tsai YQ Chen CJ, Tsai, YT, Hung TF, et al. (2015) Ternary spinel $\mathrm{MCO}_{2} \mathrm{O}_{4}(\mathrm{M}=\mathrm{Mn}, \mathrm{Fe}, \mathrm{Ni}$, and $\mathrm{Zn})$ porous nanorods as bifunctional cathode materials for lithium- $\mathrm{O}_{2}$ batteries. Acs Appl Mater Inter 7(22): 12038-12046.

44. Ilyas A, Ashraf MY, Hussain M, Ashraf M, Ahmed R, et al. (2015) Effect of micronutrients $(\mathrm{Zn}, \mathrm{Cu}$ and $\mathrm{B}$ ) on photosynthetic and fruit yield attributes of citrus reticulata Blanco var. kinnow. Pak J Bot 47(4): 12411247.

45. Khosa SS, Younis A, Rayit A, Yasmeen S, Riaz A (2011) Effect of foliar application of macro and micronutrients on growth and flowering of Gerbera jamesonii L. Amer Euras J Agric Environ Sci 11: 736-757.

46. Avin-Wittenberg T, Baluška F, Bozhkov PV, Elander PH, Fernie AR, et al. (2018) Autophagy-related approaches for improving nutrient use efficiency and crop yield protection. J Exp Bot 69(6): 1335-1353.

Your next submission with Juniper Publishers
will reach you the below assets
- Quality Editorial service
- Swift Peer Review
- Reprints availability
- E-prints Service
- Manuscript Podcast for convenient understanding
- Global attainment for your research
- Manuscript accessibility in different formats
( Pdf, E-pub, Full Text, Audio)
- Unceasing customer service
Track the below URL for one-step submission
https://juniperpublishers.com/online-submission.php

